\title{
Antibacterial and cytotoxic activity from basidiocarp extracts of the edible mushroom Lactarius indigo (Schw.) Fr. (Russulaceae)
}

\author{
Alejandra Ochoa-Zarzosa ${ }^{1}$, Ma. Soledad Vázquez-Garcidueñas ${ }^{2}$, Virginia A. Robinson- \\ Fuentes $^{2}$ and Gerardo Vázquez-Marrufo ${ }^{1 *}$
}

\author{
${ }^{1}$ Centro Multidisciplinario de Estudios en Biotecnología, Facultad de Medicina Veterinaria y Zootecnia. \\ ${ }^{2}$ División de Estudios de Posgrado, Facultad de Ciencias Médicas y Biológicas "Dr. Ignacio Chávez", Universidad \\ Michoacana de San Nicolás de Hidalgo, Morelia, Michoacán, México.
}

Accepted 18 February, 2011

\begin{abstract}
Aqueous and organic basidiocarp extracts of the edible mushroom Lactarius indigo were evaluated for their antibacterial and cytotoxic effects. 10,20 and $30 \mathrm{mg}$ of organic extracts were tested against diarrheagenic Escherichia coli strains (EIEC, EPEC, ETEC-LT and ETEC-ST), Pseudomonas aeruginosa, Enterobacter cloacae, Staphylococcus aureus and Salmonella enterica. $10 \mathrm{mg}$ of hexane extract showed activity against ETEC-LT (18.8 $\mathrm{mm}$ zone of inhibition) and $P$. aeruginosa $(10.5 \mathrm{~mm})$. All levels of the ethyl acetate extract inhibited all the strains, with stronger activity against EIEC $(19.0 \mathrm{~mm})$ and $P$. aeruginosa $(21.0 \mathrm{~mm})$ at $30 \mathrm{mg}$. Methanol extract inhibited all bacterial growth, but $E$. cloacae. $100 \mu \mathrm{g} / \mathrm{ml}$ of aqueous extract showed antiproliferative activity against MCF7 cells, but not on HeLa, A549 and normal bovine mammary epithelium cells. Methanol and ethyl acetate extracts inhibited proliferation of HeLa cells (50 to $1000 \mathrm{ng} / \mathrm{ml}$ ) but increased proliferation of A549 $(100 \mathrm{ng} / \mathrm{ml})$, as did methanol extract $(500 \mathrm{ng} / \mathrm{ml})$. Methanol extract did not inhibit normal rabbit serum fibroblast cells, while hexane and ethyl acetate extracts showed an inhibitory effect with 50 and $100 \mathrm{ng} / \mathrm{ml}$, respectively, less than in proliferation of HeLa cells. These results show that $L$. indigo basidiocarps contain substances with antibacterial and cytotoxic activities.
\end{abstract}

Key words: Lactarius indigo extracts, antibacterial activity, cytotoxic activity.

\section{INTRODUCTION}

Fungi from the division Basidiomycota have been widely studied as an alternative source of metabolites with pharmacological properties, including anticancerigenous, antitumor, immunomodulating, antibacterial and cytotoxic activities (Wasser, 2002; Daba and Ezeronye, 2003; Fan et al., 2006; Borchers et al., 2008). Antibiotic resistance of human pathogenic bacteria has become a major worldwide public health concern (Finch, 2002; Harbarth and Samore, 2005), this is why the search for new substances with antimicrobial activity is a priority (Livermore, 2005). Antimicrobial activity has already been documented in extracts from the mycelium (Suay et al., 2000) and fruiting bodies (Zjawioney, 2004) of differ-

\footnotetext{
*Corresponding author. E-mail: gvazque-zmarrufo@yahoo.com.
} mx. Tel/Fax: + 524432958029 . rent wild species from Basidiomycota.

Another worldwide public health problem is cancer, given that it is estimated that approximately 25 million people suffer one of its different manifestations and 10 million new cases are annually reported (WHO, 2002); for that reason, there is an increasing demand for more effective anticancerigenous substances and therapies (Lord and Ashworth, 2010). In that regard, several studies have reported cytotoxic activity against cancer cells of organic extracts of spores (Fukuzawa et al., 2008), vegetative mycelium (Hu et al., 2002; Choi et al., 2004) and basidiocarps (Takaku et al., 2001; Hu et al., 2002) from several species of Basidiomycota. The genus Lactarius (Russulaceae) includes species reported as edible in different parts of the world (Boa, 2004) and reports exist of the antimicrobial activity of methanol extracts of Lactarius deterrimus, Lactarius sanguifluus, Lactarius semisanguifluus, Lactarius piperatus, Lactarius 
deliciosus and Lactarius salmonicolor (Dulger et al., 2002; Barros et al., 2007a, b). In addition, the organic extracts of some Lactarius species have shown immunomodulating, cytotoxic, antiviral and antigenotoxic activities (Krawczyk et al., 2003, 2005, 2006; Mlinaric et al., 2004).

Lactarius indigo (Schw.) Fr. is an edible mushroom that distributed from East Asia (China and Japan) (Wu and Mueller, 1997) to Northeastern and Central America (Hesler and Smith, 1979; Hutchinson, 1991; Mueller and Halling, 1995; Montoya and Bandala, 1996; Wu and Mueller, 1997). In México, L. indigo is associated to diverse plant communities (Montoya and Bandala, 1996) and is highly valued as food (Boa, 2004; Pérez et al., 2006), being sold in local markets (Montoya et al., 2001; Martínez-Carrera et al., 2005). It is known by the Spanish common names indigo, hongo azul (blue mushroom) and the combined Spanish-Nahuatl names tecax azul (blue tecax) and tecosan morado (purple tecosan) (Montoya et al., 2001, 2003).

A single report is known about the nutritional value of $L$. indigo (León-Guzmán et al., 1997); however, there is not a single report regarding the pharmacological properties of this species. In the present work, the antibacterial and cytotoxic activities of aqueous and organic extracts of $L$. indigo are evaluated for the first time and the results are compared with those from similar reports for other species of Basidiomycota, mainly for the genus Lactarius.

\section{MATERIALS AND METHODS}

\section{Basidiocarp collection}

Basidiocarps of $L$. indigo were collected in the Parque Nacional Insurgente José María Morelos in the municipality of Charo, state of Michoacán, México (19³9.918' N, $101^{\circ} 00.450^{\prime}$ W) on September 2006, and were authenticated by M.Sc. Marlene Gómez Peralta, curator of the herbarium of the Facultad de Biología, Universidad Michoacana de San Nicolás de Hidalgo, where a voucher specimen (KM03) was deposited. The basidiocarps were frozen at $-80^{\circ} \mathrm{C}$ the same day of collection and freeze-dried after $24 \mathrm{~h}$. The freeze-dried material was preserved in the dark at $4^{\circ} \mathrm{C}$ in a container with silica gel until processed.

\section{Test microorganisms}

Strains of Escherichia coli EPEC, ETEC, and EIEC pathotypes used for the antibacterial activity assays were purchased from the Institute of Diagnostic and Epidemic Reference of México (InDRE, Table 1). The Children's Hospital Eva Sámano de López Mateos of Morelia, Michoacán, Mexico, donated the tested strains of Pseudomonas aeruginosa, Enterobacter cloacae, and Salmonella enterica subsp. enterica. The tested strain of Staphylococcus aureus was ATCC27543.

\section{Cell lines}

Several cell lines corresponding to human cancers were used for the cytotoxicity assays: HeLa (cervicouterine cancer), MCF7 (breast cancer) and A549 (lung cancer). As controls for evaluating the effect on normal cells, bovine mammary epithelial cells (BME) were used for assays with aqueous extracts, and rabbit skin fibroblasts (RSF) for assays with organic extracts. The latter two cell lines were generated in our laboratory. All cell lines were kept in Dulbecco's modified Eagle's medium (DMEM)-F12K (1:1, Sigma, USA) supplemented with $30 \mathrm{mM} \mathrm{NaHCO}, 15 \%$ fetal bovine serum (Gibco, USA), $50 \mathrm{U} / \mathrm{ml}$ of penicillin and $50 \mathrm{U} / \mathrm{ml}$ of streptomycin (Gibco, USA). Cells were cultured at $37^{\circ} \mathrm{C}$ in an atmosphere with $5 \% \mathrm{CO}_{2}$ and $95 \%$ humidity.

\section{Extract preparation}

For obtaining the aqueous extract $100 \mathrm{~g}$ (dry weight) of basidiocarp mass was boiled in $700 \mathrm{ml}$ of deionized water for $60 \mathrm{~min}$, continuously replacing the evaporated water during the extraction time. After extraction was completed the residual biomass was eliminated by filtration through sterile gauze. The recovered filtrate was lyophilized and resuspended in deionized water at a concentration of $500 \mathrm{mg} / \mathrm{ml}$. The resulting solution of aqueous extract was sterilized by filtering through a $0.25 \mu \mathrm{m}$ pore size membrane (Millipore, USA) and stored at $4^{\circ} \mathrm{C}$.

Organic extracts were prepared by crushing $50 \mathrm{~g}$ of freeze-dried basidiocarp until a fine powder was obtained; the resulting material was successively extracted with $100 \mathrm{ml}$ of each hexane, ethyl acetate, and methanol during $72 \mathrm{~h}$. The extracts were later centrifuged at $1500 \times \mathrm{g}$ at room temperature and filtered. The solvents were eliminated by rotoevaporation until dryness and the dry extracts were stored at $4^{\circ} \mathrm{C}$. Solutions for the bioassays were prepared by resuspending the dry extracts in the same solvent used for the extraction at a concentration of $500 \mathrm{mg} / \mathrm{ml}$.

\section{Bioassays}

\section{Antimicrobial activity by disk diffusion method}

The antimicrobial assays were performed in vitro using the agardisk diffusion method (National Committee for Clinical Laboratory Standards, 1993). Petri dishes with Mueller-Hinton Agar (Oxoid, USA) were inoculated massively with a $200 \mu \mathrm{l}$ suspension of each of the bacterial cultures and grown to their mid-log phase, after which the plate's surfaces were air-dried. Filter paper sensidisks (6 $\mathrm{mm}$ in diameter) were impregnated with the necessary volume of each of the extracts in order to reach the final levels of 10,20 , and $30 \mathrm{mg} /$ disk. The impregnated sensidisks were air-dried before being placed on the Petri dishes with the test microorganisms. The plates were incubated for $24 \mathrm{~h}$ at $37^{\circ} \mathrm{C}$ and the inhibition areas were measured in $\mathrm{mm}$ using a digital caliper (precision of $0.01 \mathrm{~mm}$, Model CD-6" C, Mitutoyo Corp., Japan). Controls consisted of sensidisks impregnated with the corresponding pure solvent and air-dried. The inhibition diameter of the control disk was subtracted from the inhibition diameter resulting from the application of the corresponding extracts of $L$. indigo. In some tests, control sensidisks with ampicillin ( $A M$ ) and carbenicillin (CB) (BioRad, USA) were used (Table 1). All assays were performed in triplicate and the results were reported as mean \pm standard deviation (SD).

\section{Cytotoxicity assays}

For cytotoxicity assays four different concentrations were used of the organic extracts and the same volume of the corresponding solvent as a control. All tested cell lines were cultivated to confluence as described above and were detached from the culture plate using PBS saline solution at $\mathrm{pH} 7.4$ supplemented with antibiotics and $0.25 \%$ trypsin-EDTA (w/v, Sigma, USA) and agitated 
for 10 min. Afterwards, $1 \times 10^{6}$ cells were seeded in OPTIMEM (Gibco, USA) growth medium without serum or antibiotics in 96-well microtitration plates. To these cultures the corresponding extract was added incubating the treated plates during 24 to $48 \mathrm{~h}$ at $37^{\circ} \mathrm{C}$. After incubation, $10 \mu \mathrm{l}$ of a $5 \mathrm{mg} / \mathrm{ml}$ solution of tetrazolium bromide 3-(4,5-dimetil-2-tiazol)-2,5-diphenil-2H-tetrazolium salt (MTT, Sigma, USA) were added and further incubated for $4 \mathrm{~h}$ at $37^{\circ} \mathrm{C}$. Finally, $100 \mu \mathrm{l}$ of $10 \%$ SDS were added in order to dissolve the formazan crystals and the viability of cells was determined by measuring the reduction of MTT at $595 \mathrm{~nm}$ in a microplate reader (Bio-Rad, USA). Each assay was carried out at least in sextuplicate.

\section{Statistical analysis}

In order to evaluate the effect of the extract concentration on the different studied strains and cell lines, the results were analyzed by one-way analysis of variance (ANOVA) and Tukey tests $(p<0.05)$, using StatistiXL ver. 1.8 .

\section{RESULTS}

\section{Antibacterial activity}

The controls showed that hexane alone did not cause any inhibition to the tested strains whereas the ethyl acetate and methanol caused a minimal inhibition that was subtracted as described in Materials and Methods. The hexane extract caused inhibition of $P$. aeruginosa and ETEC-LT (Table 2). For the ETEC-LT strain, 10 and $20 \mathrm{mg}$ of hexane extract did not show significant differences in the inhibition zone diameter but $30 \mathrm{mg}$ caused a significantly larger inhibition zone diameter than that for lower amounts. For $P$. aeruginosa, the maximum inhibition was observed at $20 \mathrm{mg}$ of hexane extract, since no significant differences could be observed with 20 and $30 \mathrm{mg}$ of the extract (Table 2). The compounds present in the hexane extract had a greater effect on the ETEC-LT strain than on $P$. aeruginosa. The inhibition caused by the hexane extract is comparable with that caused by the standard antibiotics AM and CB (Table 1).

The ethyl acetate extract inhibited all tested strains (Table 2). In all strains, except for ETEC-LT and $S$. enterica, an apparent dose-response effect could be observed, since the inhibition increased in relation to the applied level of ethyl acetate extract. No significant differences could be observed in $E$. cloacae and $S$. aureus when applying the two lower amounts of the extract. At $10 \mathrm{mg}$ of ethyl acetate extract, no differences could be observed in the inhibition of any of the tested microorganisms. However, at 20 and $30 \mathrm{mg}$ of ethyl acetate extract, significant differences were observed in the inhibition of $P$. aeruginosa, EIEC, ETC-ST, and EPEC (Table 2). At the highest level, all strains showed different susceptibilities to the ethyl acetate extract, except for $E$. cloacae and $S$. aureus. The inhibition of the different $E$. coli pathotypes caused by $30 \mathrm{mg}$ of the ethyl acetate extract was comparable to that caused by $A M$ and $C B$, except for strain ETEC-LT (Table 1).
The methanol extract caused inhibition in all bacteria tested. Only E. cloacae did not show susceptibility at 10 $\mathrm{mg}$ (Table 2). At this level, $S$. enterica and $P$. aeruginosa were much more susceptible than the other tested bacteria. With $20 \mathrm{mg}$ of the methanol extract, the inhibitory effect was greater in the ETEC-LT and EIEC strains, whereas EPEC was less susceptible. Even though the inhibition effect caused by the methanol extract differed little from that caused by the other tested extracts, the differences were statistically significant. Using $30 \mathrm{mg}$ of methanol extract, EIEC and E. cloacae exhibited the greatest inhibition, followed by ETEC-ST and $S$. aureus (Table 2). The increase in level of the methanol extract had different effects among strains. The strains EIEC, EPEC, E. cloacae, and S. aureus displayed an apparent dose-response effect, with an increase in the inhibition zone diameter corresponding to the increment in amount of extract. ETEC and $P$. aeruginosa increased their inhibition zone diameter as the level of methanol extract augmented from 10 to $20 \mathrm{mg}$, but their inhibition zone did not increase when the level was raised to $30 \mathrm{mg}$ of the extract. Finally, S. enterica showed no variation in its inhibition zone diameter as the extract level increased. The different $E$. coli pathotypes showed inhibition zone diameters comparable to those caused by $A M$ and $C B$, except from ETEC-LT (Table 1).

\section{Cytotoxic activity}

The aqueous extract of $L$. indigo basidiocarp had different effects on the various cell lines tested. No antiproliferative effect of the aqueous extract was observed against the A549 and MCF7 cell lines, but it significantly inhibited the proliferation of HeLa cells at a concentration of $100 \mu \mathrm{g} / \mathrm{ml}$ (Figure 1). In the case of primary BME cells, a significant stimulation of prolife-ration was observed at a concentration of $10 \mu \mathrm{g} / \mathrm{ml}$ and no effect was observed at any other tested concen-tration.

The organic extracts of $L$. indigo also showed contrasting effects between studied cell lines. Thus, in normal RSF cells only the hexane extract showed an inhibitory effect of proliferation relative to the control at all concentrations tested (Figure 2), although the maximum inhibition value was only of $25.63 \%$ compared to the control at the maximum concentration of $1000 \mathrm{ng} / \mathrm{ml}$. The ethyl acetate extract showed significant inhibitory values at the concentrations of 100,500 and $1000 \mathrm{ng} / \mathrm{ml}$. Nevertheless, the maximum inhibition percentage was of only $20.80 \%$ relative to the control. The methanolic extract did not alter the capacity for proliferation of fibroblasts at any concentration used (Figure 2). In the case of HeLa cells, the three organic extracts had a significant inhibitory effect on proliferation at all concentrations evaluated. Using ethyl acetate extract, the maximum inhibition was observed at a concentration of $100 \mathrm{ng} / \mathrm{ml}$ with a value of $95.74 \%$, while for the metha- 
Table 1. Reference strains and clinical isolates used in the present study.

\begin{tabular}{lllcc}
\hline Strain & Pathotype/comment & Code & $\mathbf{A M}^{\mathbf{a}}$ & $\mathbf{C B}^{\mathbf{a}}$ \\
\hline E. coli & Enterotoxigenic with heat-labile toxin (ETEC-LT) & $\mathrm{H} 10407$ & 18.0 & 17.0 \\
& Enterotoxaemia with heat-stable toxin (ETEC-ST) & 25611 & 16.0 & 18.0 \\
& Enteroinvasive (EIEC) & $\mathrm{E} 11$ & 20.0 & 12.0 \\
& Enteropathogenic (EPEC) & $\mathrm{O} 111$ & 15.0 & 12.0 \\
S. aureus & isolated from bovine mastitis & ATCC27543 & $\mathrm{nt}$ & $\mathrm{nt}$ \\
P. aeruginosa & clinical isolate & VGPM01 & $\mathrm{nt}$ & $\mathrm{nt}$ \\
E. cloacae & clinical isolate & VGEM17 & $\mathrm{nt}$ & $\mathrm{nt}$ \\
S. enterica subsp. enterica & clinical isolate & VGSM33 & $\mathrm{nt}$ & $\mathrm{nt}$ \\
\hline
\end{tabular}

${ }^{a}$ Inhibition zone diameter ( $\mathrm{mm}$ ) caused by $10 \mu \mathrm{g}$ of ampicillin (AM) and $100 \mu \mathrm{g}$ of carbenicillin (CB), nt, not tested.

Table 2. Antibacterial activity of the organic extracts of $L$. indigo*.

\begin{tabular}{|c|c|c|c|c|c|c|c|c|c|}
\hline \multirow{3}{*}{ Bacteria } & \multicolumn{3}{|c|}{ mg/disk of each extract } & & & & & & \\
\hline & \multicolumn{3}{|c|}{ Hexane } & \multicolumn{3}{|c|}{ Ethyl acetate } & \multicolumn{3}{|c|}{ Methanol } \\
\hline & 10 & 20 & 30 & 10 & 20 & 30 & 10 & 20 & 30 \\
\hline \multicolumn{10}{|l|}{ E. coli } \\
\hline EIEC & - & - & - & $9.6(0.58)^{1, a}$ & $14.0(0.73)^{1, b}$ & $19.0(0.58)^{1, c}$ & $11.3(0.53)^{1, a}$ & $16.0(0.31)^{1, b}$ & $20.6(0.31)^{1, c}$ \\
\hline EPEC & - & - & - & $9.3(0.52)^{1, \mathrm{a}}$ & $12.0(0.50)^{2,3, b}$ & $15.3(0.15)^{2, c}$ & $11.0(0.78)^{1, \mathrm{a}}$ & $12.3(0.22)^{2, b}$ & $14.3(0.58)^{2,5, \mathrm{c}}$ \\
\hline ETEC-LT & $18.8(0.73)^{1, a}$ & $18.6(0.30)^{1, a}$ & $21.0(0.80)^{1, b}$ & $10.5(0.73)^{1, a}$ & $11.3(0.53)^{3,5, a}$ & $12.0(0.78)^{3, a}$ & $11.6(0.15)^{1, a}$ & $17.0(0.73)^{1, b}$ & $17.6(0.15)^{3, b}$ \\
\hline ETEC-ST & - & - & - & $10.0(0.19)^{1, a}$ & $13.0(0.75)^{1,2, b}$ & $17.1(0.53)^{4, c}$ & $10.7(0.58)^{1, a}$ & $15.0(0.31)^{3, b}$ & $16.0(0.73)^{3,4, b}$ \\
\hline$P$. aeruginosa & $10.5(0.51)^{2, a}$ & $11.2(0.75)^{2, a b}$ & $12.1(0.52)^{2, b}$ & $9.6(0.33)^{1, \mathrm{a}}$ & $17.2(0.25)^{4, b}$ & $21.0(0.65)^{5, \mathrm{c}}$ & $13.3(0.53)^{2, a}$ & $15.1(0.53)^{3, b}$ & $15.3(0.15)^{4, b}$ \\
\hline E. cloacae & - & - & - & $9.7(0.36)^{1, a}$ & $10.1(0.75)^{5, a}$ & $13.5(0.17)^{6, b}$ & - & $13.6(0.15)^{4, a}$ & $19.0(0.73)^{1, b}$ \\
\hline S. aureus & - & - & - & $10.1(0.29)^{1, a}$ & $11.3(0.65)^{3,5, a}$ & $13.0(0.73)^{3,6, b}$ & $9.6(0.18)^{3, a}$ & $14.0(0.78)^{3,4, b}$ & $16.3(0.29)^{3, c}$ \\
\hline S. enterica & - & - & - & $9.7(0.75)^{1, \mathrm{a}}$ & $11.0(0.58)^{3,5, a}$ & $11.0(0.59)^{7, a}$ & $13.2(0.38)^{2, a}$ & $13.7(0.17)^{4, a}$ & $13.6(0.15)^{5, a}$ \\
\hline
\end{tabular}

${ }^{*}$ The mean radius of the inhibition zone of three independent experiments is shown in $\mathrm{mm}( \pm \mathrm{SD})$. Values in the same row with the same superscript letter have non-significant differences between them. Values in the same column with the same superscript number have non-significant differences between them. For both rows and columns, the significance test was evaluated at $p<0.05$. This significance analysis was made only for results within the same kind of extract for all levels tested.

- , no inhibition zone.

nolic extract the percentage inhibition value at the same concentration was of $67.61 \%$. The hexane extract caused maximum inhibitory activity $(76.51 \%)$ at $500 \mathrm{ng} / \mathrm{ml}$. MCF7 cells showed a significant stimulation of proliferation at different concentrations of hexane and methanol extracts (Figure 2), the response was higher for the hexane extract at a concentration of $100 \mathrm{ng} / \mathrm{ml}$ with a value of $98.08 \%$

\section{DISCUSSION}

The present work shows that organic extracts from $L$. indigo are active against $E$. coli diarrheagenic strains and other bacteria that are pathogenic to humans. This is the first study in which basidiocarps of the genus Lactarius are tested against different $E$. coli diarrheagenic strains. Some of the tested strains showed significant differences in their responses to the extracts. The ETEC-LT pathotype was susceptible 


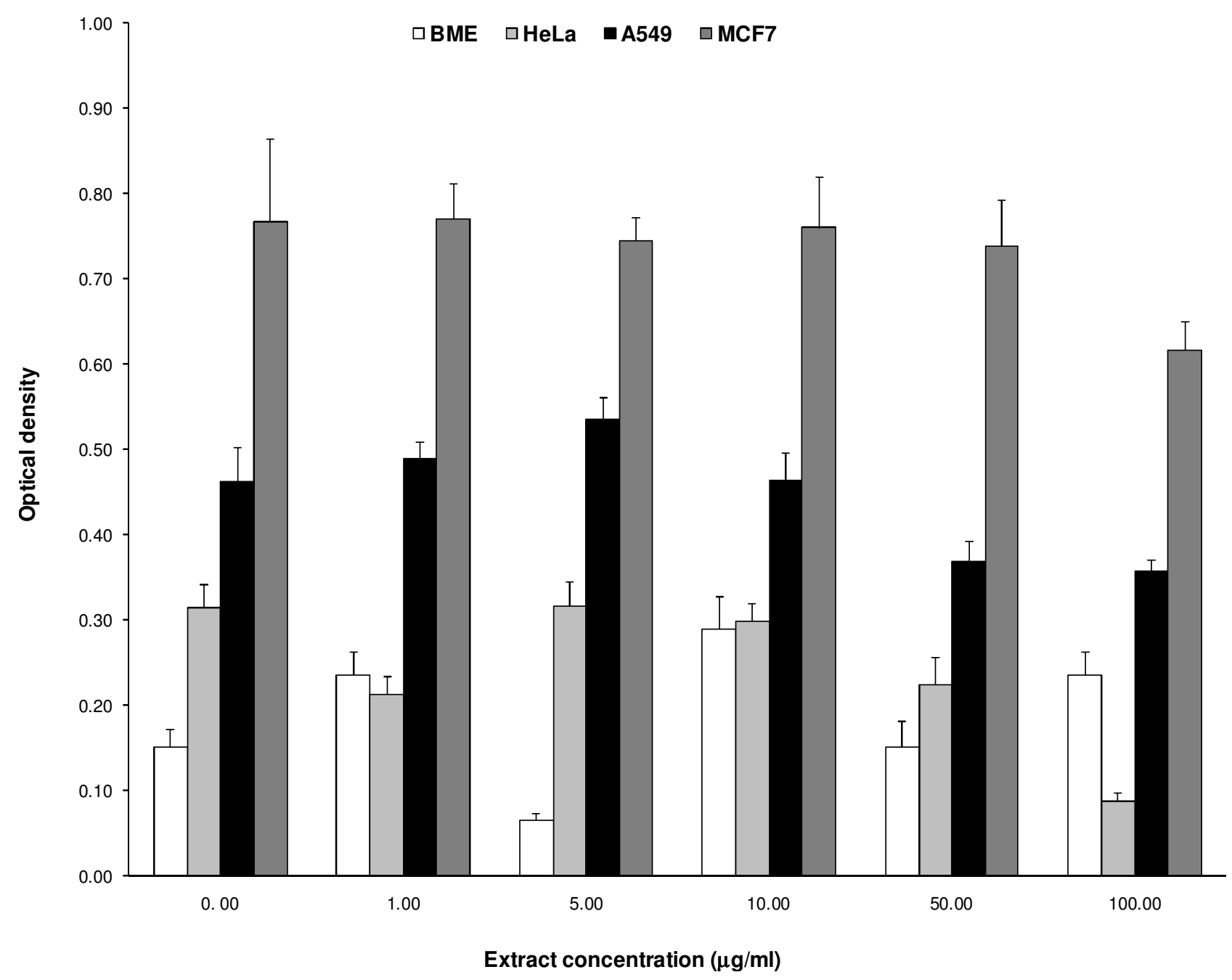

Figure 1. Effect of aqueous extract of $L$. indigo basidiocarp on proliferation of the four cell types evaluated. Bars represent the mean of sextuplicates with its relative standard error. Asterisks indicate extract doses having significant differences relative to the control (deionized water).

to the hexane extract whereas the EIEC pathotype was more susceptible to the ethyl acetate and methanol extracts. Our results agree with those reported by Dulger et al. (2002), who documented the activity against $E$. coli of methanol extracts of different species of Lactarius, although they used a non-pathogenic strain. There are some reports about the effect of methanol extracts of Lactarius deliciosus on E. coli, with very contrasting results. On one side, extracts of $L$. deliciosus collected in Portugal had no activity against non-diarrheagenic $E$. coli (Barros et al., 2007a, b); on the other extreme, basidiocarp extracts of the same species collected in Turkey gave positive inhibitory results against a different strain of non-diarrheagenic E. coli (Dulger et al., 2002). Methanolic extracts of Lactarius piperatus inhibited growth of E. coli, but its activity was dependent on the maturity of the basidiocarp used to make the extracts (Barros et al., 2007b). These results may be due to differences in the susceptibilities of the different strains tested, although differences in the chemical composition of the basidiocarps and in the extraction methods cannot be discarded. In relation to the other microorganisms tested, the three extracts showed strong activity against $P$. aeruginosa and only the methanol extract exhibited activity against $E$. cloacae and $S$. aureus. These results agree with other reports stating that $P$. aeruginosa and $S$. aureus can be inhibited by methanol extracts of basidiocarps of species in the genus Lactarius (Dulger et al., 2002; Barros et al., 2007a, b). However, the inhibition activity of the methanol extract of $L$. indigo on $S$. aureus that was observed in the present work seems to be greater than the activity previously reported for methanol extracts of other species in the same genus (Dulger et al., 2002). No previous reports were found about the inhibition of E. cloacae using extracts of species of the genus Lactarius. 

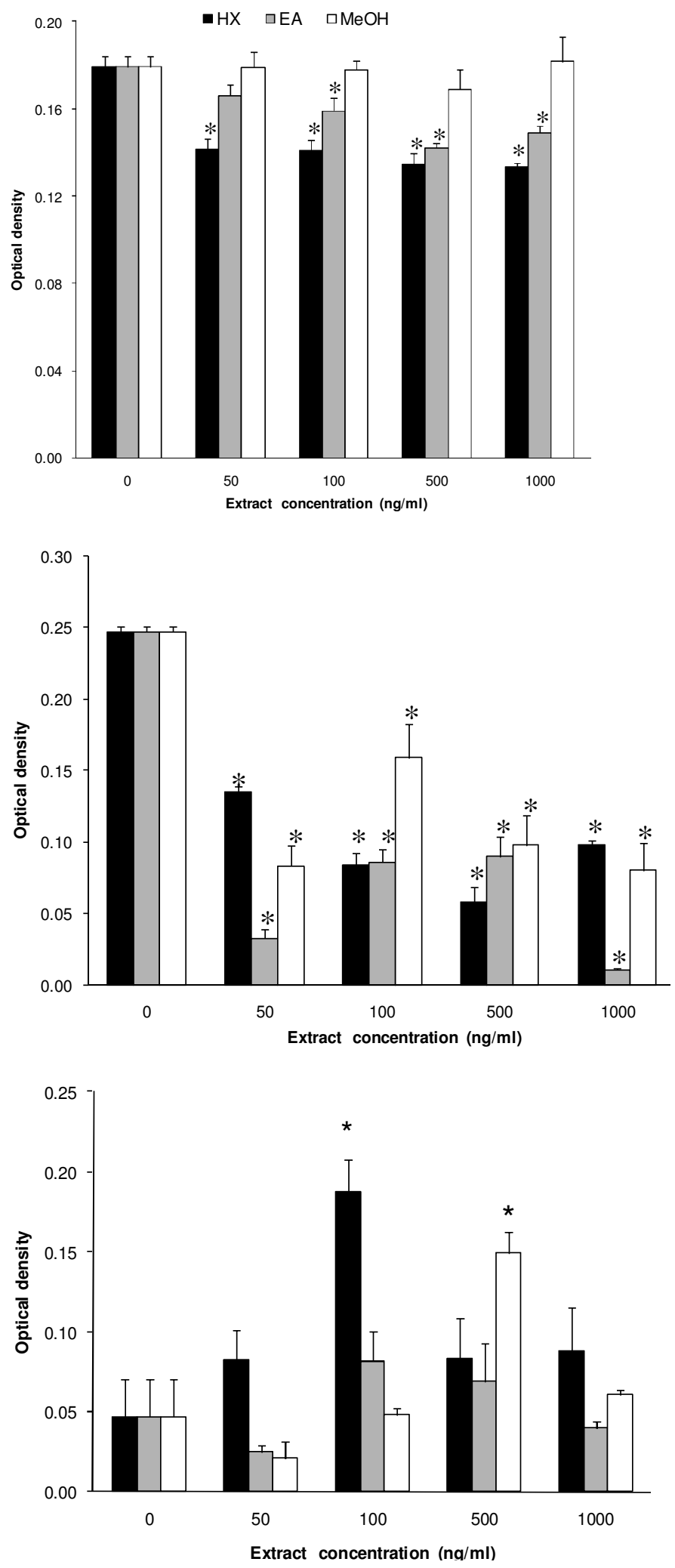

Figure 2. Effect of hexane (HX), ethyl acetate (EA) and methanolic $(\mathrm{MeOH})$ extracts of $L$. indigo basidiocarp on the proliferation of normal RSF (upper panel), HeLa (middle panel) and MCF7 (bottom panel) cell lines. Bars represent the mean of sextuplicates with its relative standard error. Asterisks indicate extract doses with significant differences relative to the control (pure solvent).
The inhibition caused by the ethyl acetate and methanol extracts was observed in practically all tested strains. Therefore, it can be hypothesized that the basidiocarps from $L$. indigo contain a wide spectrum of antibacterial compounds. It has been previously established that compounds with antibacterial activity extracted from species in the genus Lactarius are mainly sesquiterpenes (Anke et al., 1989; Vidari et al., 1995). Further studies are now needed to elucidate the chemical structure of the antibacterial compounds extracted from basidiocarps of $L$. indigo.

In the present work the aqueous extract of $L$. indigo significantly inhibited the proliferation of HeLa cells and showed a significant stimulatory effect on the proliferation of primary BME cells. These results contrast with reports for other species of Basidiomycota, although at significantly higher concentrations of aqueous extract than those used in the present study. For example, the aqueous extracts of Coprinellus sp., Flammulina velutipes and Coprinus comatus were capable of inhibi-ting the proliferation in vitro of MCF7 cells, with $\mathrm{IC}_{50}$ values of 120,150 and $450 \mu \mathrm{g} / \mathrm{ml}$, respectively (Gu and Leonard, 2006). Consequently, we cannot discard the possibility that the aqueous extract of $L$. indigo may present antiproliferative activity against the other cell lines evaluated in the present work at higher concentrations than those used by us, a possibility that needs to be evaluated in future works. On the other side, the fact that low concentrations of the aqueous extract had a significant stimulatory effect on the proliferation of normal BME cells is indicative of the possibility that the chemical compounds in the aqueous extract of $L$. indigo, which inhibit the proliferation of HeLa cells may be specific against certain types of cancerous cells. This fact is relevant given that not all aqueous extracts of Basidiomycota present a specific activity against cancer cells; for example, the vegetative mycelia of Funalia trogii and of Trametes (Coriolus) vers-icolor contain water-soluble metabolites that inhibit the proliferation of both HeLa and normal fibroblasts (Ünyayar et al., 2006). One possibility is that the aqueous extract of $L$. indigo contains active polysaccharides that are specific against cancer cell lines. One polysaccharide has been isolated from the aqueous extract of Pleuotus ostreatus that has an antiproliferative effect against $\mathrm{HeLa}$ cells at concentrations of 100,200 and $400 \mu \mathrm{M}$, but that has no significant inhibitory effect on normal human embryonic kidney cells 293T (Tong et al., 2009). Recently, a polysaccharide enriched with selenium was obtained from an aqueous extract of vegetative mycelium of Ganoderma lucidum that displays a high antiproliferative activity in vitro against HeLa and MCF7 cells with $\mathrm{IC}_{50}$ values of 0.17 and $0.14 \mu \mathrm{M}$, respectively (Shang et al., 2009). The determination and characterization of anticarcinogenic polysaccharides in aqueous extracts of $L$. indigo is certainly an essential task to be carried out.

The organic extracts of the basidiocarp of $L$. indigo did not show cytotoxic activity against the MCF7 cell line but 
were capable for inhibiting the proliferation of HeLa cells. While ethyl acetate and methanol extracts showed a significant inhibitory effect of proliferation on normal RSF, this was relatively low. Regarding MCF7 cells, the results of our study contrast with those of several previous reports about the effect of organic extracts of Basidiomycota. Thus, methanolic extracts of Pleurotus ostreatus significantly inhibit the proliferation in vitro of MCF7 cells at concentrations above $120 \mu \mathrm{g} / \mathrm{ml}$ (Jedinak and Sliva, 2008). Such extracts induce the arrest of the cell cycle at the G0/G1 transition by means of induction of the expression of p53 and p21 proteins, which inhibit the cyclinkinase complexes (CDK). Analyses have been made of the antiproliferative effects of the organic extracts of the Basidiomycota fungus Naematoloma fasciculare as well as those of the unsaturated aliphatic acids, ergosterol and ergosterol peroxide, isolated from such extracts (Yan et al., 2009). The pure chemical compounds showed an antiproliferative effect against MCF7 cells that is from 10 to 100 times larger than that of the extracts; while for the former the $\mathrm{IC}_{50}$ values oscillated between 0.16 and $1.54 \mathrm{\mu g} / \mathrm{ml}$, in the latter case those values varied from 13.80 to over $30.0 \mu \mathrm{g} / \mathrm{ml}$ (Yan et al., 2009). Triterpenoids isolated by means of extraction with ethyl acetate of basidiocarp of Leucopaxillus gentianeus showed a high antiproliferative activity against MCF7 cells, some of these compounds having $\mathrm{IC}_{50}$ values lower than 300 $\mu \mathrm{M}$ (Clericuzio et al., 2004).

In contrast with the case of the MCF7 cells, our results with HeLa cells agree with a number of literature reports. Thus, the inhibition of proliferation of HeLa cells by ethanolic extracts of spores of $G$. lucidum has been reported (Fukuzawa et al., 2008), an effect that was attributed to long chain fatty acids; however, there is a recent report of triterpenoids of the same species having high cytotoxic potential against HeLa cells (Cheng et al., 2010).

An interesting observation made during the present work is the stimulation of the proliferation of the MCF7 cell line, an activity that has been previously reported for aqueous extracts of Agaricus blazei in the presence of the estrogenic compound nonylophenol (Talorete et al., 2002). Such proliferative activity has been associated with induction of the expression of the c-Jun protein by the extract, which is synthesized by one of the genes from the proto-oncogene family $c$-jun, characterized by being induced by mitogenic agents (Talorete et al., 2002). Because the MCF7 cell line is characterized by presenting estrogen receptors, it is possible that the organic extracts of $L$. indigo may contain a substance that stimuli-tes those receptors, something to be analyzed in the future.

\section{Conclusion}

Both aqueous and organic extracts of $L$. indigo basidiocarp posses pharmacological activity; in some cases, due to inhibition of the proliferation capacity of pathogenic bacteria, and in others, that of carcinogenic cells, without significantly affecting normal cells. Our results show that the basidiocarp of the edible $L$. indigo is a source of pharmacological substances having diverse therapeutic applications, which makes it necessary to perform further studies in that regard by isolating and characterizing the molecules responsible for the observed activities.

\section{ACKNOWLEDGEMENTS}

The authors acknowledge Silvia Martínez Chávez and Monia Hernández Ayala for their technical assistance in the cytotoxicity assays, and Verónica García Quiroz for her help in the antimicrobial experiments.

\section{REFERENCES}

Anke H, Bergendorff O, Sterner O (1989). Assays of the biological activities of guaiane sesquiterpenoids isolated from the fruit bodies of edible Lactarius species. Food Chem. Toxicol., 27(6): 393-397.

Barros L, Calhelha RC, Vaz JA, Ferreira ICFR, Baptista P, Estevinho LM (2007a). Antimicrobial activity and bioactive compounds of Portuguese wild edible mushrooms methanolic extracts. Eur. Food Res. Technol., 225(2): 151-156.

Barros L, Baptista P, Estevinho LM, Ferreira IC (2007b). Effect of fruiting body maturity stage on chemical composition and antimicrobial activity of Lactarius sp. Mushrooms. J. Agric. Food Chem., 55(21): 8766-8771.

Boa E (2004). Wild edible fungi: A global overview of their use and importance to people. Non-Wood Forest Products Report no. 17. Food and Agriculture Organization of the United Nations, Rome. Available via www.fao.org/docrep/007/y5489e/y5489e00.htm

Borchers AT, Krishnamurthy A, Keen CL, Meyers FJ, Gershwin ME (2008). The immunobiology of mushrooms. Exp. Biol. Med., 233(3): 259-276.

Choi, YH, Huh MK, Ryu CH, Choi BT, Jeong YK (2004). Induction of apoptotic cell death by mycelium extracts of Phellinus linteus in human neuroblastoma cells. Int. J. Mol. Med., 14(2): 227-232.

Clericuzio M, Mella M, Vita-Finzi P, Zema M, Vidari G (2004). Cucurbitane triterpenoids from Leucopaxillus gentianeus. J. Nat. Prod., 67(11): 1823-1828.

Daba AS, Ezeronye OU (2003). Anti-cancer effect of polysaccharides isolated from higher basidiomycetes mushrooms. Afr. J Biotechnol., 2 (12): 672-678.

Dulger B, Yilmaz F, Gucin F (2002). Antimicrobial activity of some Lactarius species. Pharm. Biol., 40(4): 304-306.

Fan L, Pan H, Soccol AT, Pandey A, Soccol CR (2006). Advances in mushrooms research in the last decade. Food Technol. Biotechnol., 44(3): 303-311.

Finch R (2002). Bacterial resistance- the clinical challenge. Clin. Microbiol. Infect. 8 (Suppl 3): 21-32.

Fukuzawa M, Yamaguchi R, Hide I, Chen Z, Hirai Y, Sugimoto, A, Yasuhara T, Nakata Y (2008). Possible involvement of long chain fatty acids in the spores of Ganoderma lucidum (Reishi Houshi) to its anti-tumor activity. Biol. Pharm. Bull., 31(10): 1933-1937.

$\mathrm{Gu} \mathrm{YH}$, Leonard J (2006). In vitro effects on proliferation, apoptosis and colony inhibition in ER-dependent and ER-independent human breast cancer cells by selected mushroom species. Oncol. Rep., 15(2): 417 423.

Harbarth S, Samore MH (2005). Antimicrobial resistance determinants and future control. Emerg. Infect. Dis., 11(6): 794-801.

Hesler LR, Smith AH (1979). North American species of Lactarius. Ann Harbor, MI, University of Michigan Press, pp. 841.

$\mathrm{Hu}$ H, Ahn NS, Yang X, Lee YS, Kang KS (2002). Ganoderma lucidum extract induces cell cycle arrest and apoptosis in MCF-7 human 
breast cancer cell. Int. J. Cancer., 102(3): 250-253.

Hutchinson LJ (1991). Description and identification of cultures of ectomycorrhizal fungi found in North America. Mycotaxon, 42(1): 387504.

Jedinak A, Sliva D (2008). Pleurotus ostreatus inhibits proliferation of human breast and colon cancer cells through p53-dependent as well as p53-independent pathway. Int. J Oncol., 33(6): 1307-1313.

Krawczyk E, Luczak M, Kobus M, Banka D, Daniewski W (2003). Antiviral activity of $\mathrm{N}$-benzoylphenylisoserinates of Lactarius sesquiterpenoid alcohols in vitro. Planta Med., 69(6): 552-554.

Krawczyk E, Luczak M, Kniotek M, Majewska A, Kawecki D, Nowaczyk M (2005). Immunomodulatory activity and influence on mitotic divisions of $\mathrm{N}$-benzoylphenylisoserinates of Lactarius sesquiterpenoid alcohols in vitro. Planta Med., 71(9): 819-824.

Krawczyk E, Kniotek M, Nowaczyk M, Dzieciatkowski T, Przybylski M, Majewska A, Luczak M (2006). N-acetylphenylisoserinates of Lactarius sesquiterpenoid alcohols - cytotoxic, antiviral, antiproliferative and immunotropic activities in vitro. Planta Med., 72 (7): 615-620.

León-Guzmán MF, Silva I, López MG (1997). Proximate chemical composition, free amino acid contents, and free fatty acid contents of some wild edible mushrooms from Querétaro, México. J. Agric. Food Chem., 45(11): 4329-4332.

Livermore D (2005). Minimising antibiotic resistance. Lancet Infect. Dis., 5(7): 450-459.

Lord CJ, Ashworth A (2010). Biology-driven cancer drug development: back to the future. BMC Biol., 8:38. Doi:10.1186/1741-7007-8-38.

Martínez-Carrera D, Nava D, Sobal M, Mayett Y (2005). Marketing channels for wild and cultivated edible mushrooms in developing countries: the case of Mexico. Micol. Apl. Int., 17(2): 9-20.

Mlinaric A, Kac J, Fatur T, Filipic M (2004). Anti-genotoxic activity of the mushroom Lactarius vellerus extract in bacteria and in mammalian cells in vitro. Pharmazie., 59(3): 217-221.

Montoya L, Bandala V (1996). Additional new records on Lactarius from Mexico. Mycotaxon, 57(1): 425-450.

Montoya-Esquivel A, Estrada-Torres A, Kong A, Juárez-Sánchez L (2001). Commercialization of wild mushrooms during market days of Tlaxcala, Mexico. Micol. Apl. Int., 13(1): 31-40.

Montoya A, Hernández-Totomoch O, Estrada-Torres A, Kong A, Caballero J (2003). Traditional knowledge about mushrooms in a Nahua community in the state of Tlaxcala, México. Mycologia, 95(5): 793-806.

Mueller G, Halling R (1995). Evidence for high Biodiversity of Agaricales (Fungi) in Neotropical Montane Quercus Forest. In: Churchill SP (ed) Biodiversity and conservation of Neotropical montane forests, The New York Botanical Garden, New York, pp. 303-312.

National Committee for Clinical Laboratory Standards (NCCLS) (1993). Performance standard for antimicrobial disc susceptibility test. Approved Standard NCCLS Publications M2-A5 (ISBN 1-56238-3779). NCCLS, 940, West Valley, Pennsylvania 19087, USA.

Pérez-Silva E, Esqueda M, Herrera T, Coronado M (2006). New records of Agaricales from Sonora, México. Rev. Mex. Biodiv., 77(1): 23-33.

Shang D, Zhang J, Wen L, Li Y, Cui Q (2009). Preparation, characterization, and antiproliferative activities of the Se-containing polysaccharide SeGLP-2B-1 from Se-enriched Ganoderma lucidum. J. Agric. Food Chem., 57(17): 7737-7742.
Suay I, Arenal F, Asensio FJ, Basilio A, Cabello MA, Díez MT, García JB, del Val A G, Gorrochategui J, Hernández P, Peláez F, Vicente MF (2000). Screening of basidiomycetes for antimicrobial activities. Antonie Van Leeuwenhoek, 78(2): 129-139.

Takaku T, Kimura Y, Okuda H (2001). Isolation o fan antitumor compound from Agaricus blazei Murril and its mechanisms of action. J Nutr., 131(5): 1409-1413.

Talorete TPN, Isoda H, Maekawa T (2002). Agaricus blazei (Class Basidiomycotina) aqueous extract enhances the expression of C-Jun protein in MCF7 cells. J. Agric. Food Chem., 50 (18): 5162-5166.

Tong H, Xia F, Feng K, Sun G, Gao X, Sun L, Jiang R, Tian D, Sun X (2009). Structural characterization and in vitro antitumor activity of a novel polysaccharide isolated from the fruiting bodies of Pleurotus ostreatus. Bioresour Technol., 100(4): 1682-1686.

A, Demirbilek M, Turkoglu M, Celik A, Mazmanci MA, Erkurt EA, Ünyayar S, Cekic Ö, Atacag H (2006). Evaluation of cytotoxic and mutagenic effects of Coriolus versicolor and Funalia trogii extracts on mammalian cells. Drug Chem. Toxicol., 29(1):69-83.

Vidari G, Vita-Finzi P, Zanocchi AM, Noy GP (1995). Bioactive tetraprenylphenol from Lactarius lignyotus. J. Nat. Prod., 58(6): 893896.

Wasser SP (2002). Medicinal mushrooms as a source of antitumor and immunomodulating polysaccharides. Appl. Microbiol. Biotechnol., 60(3):258-274

World Health Organization (WHO) (2002). National cancer control programmes: policies and managerial guidelines. $2^{\text {nd }}$ ed. Geneva.

Wu Q, Mueller GM (1997). Biogeographic relationships between the macrofungi of temperate eastern Asia and eastern North America. Can. J. Bot., 75(12): 2108-2115.

Yan D, Bao HY, Bau T, Li Y, Kim YH (2009). Antitumor components from Naematoloma fasciculare. J. Microbiol. Biotechnol., 19(10): 1135-1138.

Zjawiony KJ (2004). Biologically active compounds from Aphyllophorales (Polypore) Fungi. J. Nat. Prod., 67(2): 300-310. 